\title{
AN IMPORTANT PLACE OF WORSHIP: THE FOUNDATION OF THE RUDENI BOYARS FROM FLĂMÂNDA, THE FORMER HISTORICAL ARGES COUNTY (THE END OF THE SIXTEENTH CENTURY - THE SEVENTEENTH CENTURY)
}

\author{
Bardan (Cătălinoiu) Petruța \\ Ms. PhD., "Valahia" University of Târgoviște, Romania, ionela_pav@yahoo.com
}

\begin{abstract}
Built by Teodosie Rudeanu at the end of the sixteenth century, the monastic settlement of Flămânda, the former historical county of Arges, was part of a system of defense and refuge in the face of the external dangers, but it also served as a place of prayer for the members of the Rudeanu people, a large family of boyars from Muntenia, and not only. The land, on which the Flămânda monastery, was built was bought by Teodosie from Turcin's descendants during the first reign of Mihnea II, the voivode of Wallachia (1577-1583), when the former owners, the boyars Vlădeni and Slăvitești, went into exile.

During the reign of Mihnea III Radu (1658-1659), Teodosie's successors sued the descendants of the Slăvitești and Vlădești for the land on which Teodosie built a small monastery near Topologu River, dedicated to the „Holy Apostles Peter and Paul”. The former Flămânda hermitage was in the care of the Rudeni boyars until 1699, when the descendants of the great chancellor Tudosie gave it to the bishop llarion, thus becoming the metochion of the diocese of Râmnicu.

The Topolog hermitage owned the estates of the Baiasii on the Topolog, Turcenesti, Gardesti and Ninasesti, the former county of Arges. Of these, the Ninasesti estate belonged for a short time to the Flămânda hermitage, because the Govora Monastery claimed this estate, which they owned in the past. These estates became the property of the place of worship through the reinforcement documents issued by the chancelleries of some rulers, such as Gavril Movilă, Alexandru Coconul, or they were donated to the hermitage by the Rudeni boyars.

In the narthex of the church, on the east wall, there are the portraits of the founders: Teodosie, the son of the great chancellor Ivan from Ruda and the mistress Stanca, but also there are two tombstones, where the two spouses were buried.

The church of the former Flămânda hermitage presents the features of a classical architecture, specific to the sixteenth century, with a high, elegant structure. It is part of the trilobate churches, characterised by the building of a second tower above the narthex.
\end{abstract}

Keywords: Flămânda, hermitage, Wallachian boyars, founders, mural painting. 


\section{INTRODUCTION}

A valuable ensemble of art and architecture specific to the 16th century, the hermitage of monks from Flămânda was one of the most important places of worship built by the Rudeni boyars.

Located in the former historical county of Argeș, near the old foundation of the Rudeni from the village that contributed to the name of this nation, the place of worship is still in the middle of a courtyard surrounded by high walls, with a bell tower as a defense tower. Raw stone was used to build this bell tower (Ghika-Budești, 1932, p. 58), and the village mentioned above is the village of Ruda in the former historical Arges county (Bâzgan, 2004, p. 158). It goes without saying that the church of the former Flamanda skit is located in another village, known as the River Valley, in Galicia village, Valcea county, being located on a larger part of the land, about $29 \mathrm{~km}$ from Râmnicu Vâlcea. The place of worship built here is presented as a reinforced construction (Fig. 6), motivated by the needs of the most efficient defense in front of the Turks (Ceaușescu et al, 2012, pp. 73-74).

Like the monasteries in Maxineni, Slobozia, Cathel, Negoiesti, Comana, Draganesti, Plaviceni, Comanca, Robaia or Vodita, Flămanda's Hermitage was part of a defensive information and refuge system in the face of Turkish attacks. The architect Teodor Octavian Gheorghiu believes that the above-mentioned defense system was completed almost entirely at the beginning of the 18th century (Gheorghiu, 1985, p. 280).

The monastic Assay of Flămânda was remembered by Dionysie Fotino, in the Romanian version of his work, published in the second half of the 19th century, among the twelve "metochlors" (metohuri) in Arges County (Fotino, 1859, p. 11). Dionsie Fotino talks about fifteen small monasteries administratively subordinated to a larger monastery (metohuri), but in his work are mentioned only twelve such places of worship in Argeș County. Thus, along with Flămânda, among the twelve "metochlors", there were also Cornetu, Fedeleșoiu, Berislăvești, Buliga, Brădetu, Brătășești, Robaia, Turgu, Cotești, Teiușul and Morunglavu. To these were added three monasteries: Cotmeana, Tutana and Văleni. Therefore, only if we add the three monasteries, we reach a number of fifteen places of worship (Fotino, 1859, p. 11). Three decades later, the place of worship from Flămânda was on the list drawn up by His Eminence Ghenadie of Râmnicu, among the hermitages and "metochlors" of the Holy Episcopate of Râmnicu (Ghenadie al Râmnicului, 1888-1889, pp. 612-625). At the same time, T. G. Bulat also reminded that this monastic settlement from Galicea commune, the former historical county of Argeș, was a "metochlor" (metoh) of the Episcopate of Râmnicu (Bulat, 1922, p. 244). Later, in the Catagrafia eparhiei Argeș la anul 1824, drawn up by lon lonașcu, it was shown that the place of worship was built of wall and was "on the estate" of the Holy Episcopate of Râmnicu. The church of the former Flămâna hermitage was dedicated to the "Holy Apostles" and was located in the Topologului square (plasa), Argeș county (Ionașcu, 1942, p. 30). An attempt of this kind, to gather together the churches and their church servants from the Episcopate of Argeș in a single work, belonged, first, to Șt. Berechet, stopping, however, only in the territory of Argeș County and not in the entire Episcopate of Argeș (Berechet, 1922, pp. 678-686).

The church of the former Flămâna hermitage (Fig. 1, Fig. 2) can be found today in the list of the historical monuments in Vâlcea County, under the number 712, with the LMI code: VL II a B 09964 (Monitorul Oficial al României, 2016).

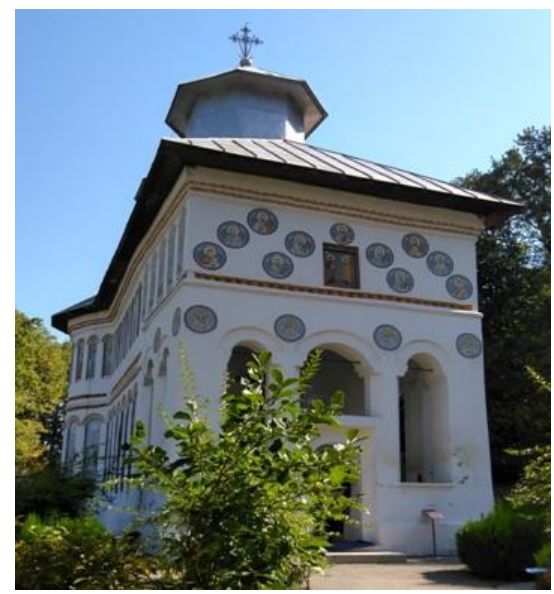

Fig. 1. The "Holy Apostles Peter and Paul" Church of the former Flămânda hermitage, Valea Râului village, Galicea commune, Vâlcea county. View from the southwest.

(Photo: Bardan Petruța, 12. 09. 2020) 


\section{METODOLOGY}

A careful analysis of internal documents, but also of other historical sources bring to light valuable information about the church "The Holy Apostles Peter and Paul" in Galicea commune, Vâlcea county. Thus, the comparison of information from historical documentary and epigraphic sources (Bălan, 1994, p. 320, doc. 396, p. 321, doc. 397), the data provided by the observations on the votive portraits of the founders of the place of worship provide certain details about the feelings of the characters represented, about their appearance, about the history of this place of worship, but also about the fashion of the time, about the dating of the place of worship or the church properties.

\section{THE CHURCH OF THE FORMER FLĂMÂNDA HERMITAGE: ABOUT ITS FOUNDERS AND CERTAIN ARCHITECTURAL ASPECTS}

The former Flâmânda hermitage was built by Teodosie Rudeanu, together with his first wife, Stanca, at the end of the 16th century (Stoicescu, 1970, p. 306). Outstanding personality of Wallachia's medieval history, Teodosie Rudeanu was one of the most important Dregators of Mihai Viteazul, Wallachia's ruler (15931601). After he was raised to the rank ofhigh official by Petru Cercel, lord of Wallachia (1583-1585), becoming High Official (vel spătar) (DIR, B, 1952, V, p. 177, doc. 189), Teodosie continued to climb the steps of a genuine Honorum coursus. During the voivode Mihai, he was, in turn, a great treasurer, between December 13, 1594 (DRH, B, 1975, XI, p. 141, doc. 103) and September 23, 1596 (DRH, B, 1975, XI, p. 273, doc. 205), and great logothetes, between 28 September 1596 (DRH, B, 1975, XI, p. 277, doc. 207) and 29 August 1599 (DRH, B, 1975, XI, p. 485, doc. 340), but also on June 1, 1600, in lași (Stoicescu, 1971 , p. 85). He remained in this latter high official, in Wallachia, during the reign of Simion Movila (1600-1602, interrupted) as well as of his son, Gavril Movila (1618-1620), between May 1 and June 21, 1602 (Mioc et al, 1960, p. 570), respectively August 20, 1618 (DIR, B, 1951, III, p. 233, doc. 208) and December 30, 1618 (DIR, B, 1951, III, p. 284, doc. 252). In addition to his involvement in the political life of Wallachia, Teodosie Rudeanu also had the merit of writing in Romanian, as head of the royal chancellery (cancellarius, logofăt), the official chronicle of the first part of the reign of Mihai Viteazul (1593-1597). There is also a Polish version of the valuable historiographical work, its translation into Latin was made by Baltazar Walther, its text being preserved, thus, to this day (Simionescu, 1959, p. 15).

From an architectural point of view, the church "The Holy Apostles Peter and Paul" fits into the category of the trilobate churches with two towers, presenting as a particularity the raising of a second tower above the narthex (Ionescu, 1965, pp. 83-84). The church is characterized by an "archaic" architecture, specific to the sixteenth century, with a tall, elegant structure. The nave has a constructive disproportion, and the narthex is square, with massive pilasters that strengthen the corners of the room. Above the narthex there is a tower, the staircase and the bell tower missing from this place. The porch in front of the place of worship is supported on octagonal pillars and was added later, as evidenced by its masonry much different from that of the narthex (Ghika-Budești, 1932, p. 33).

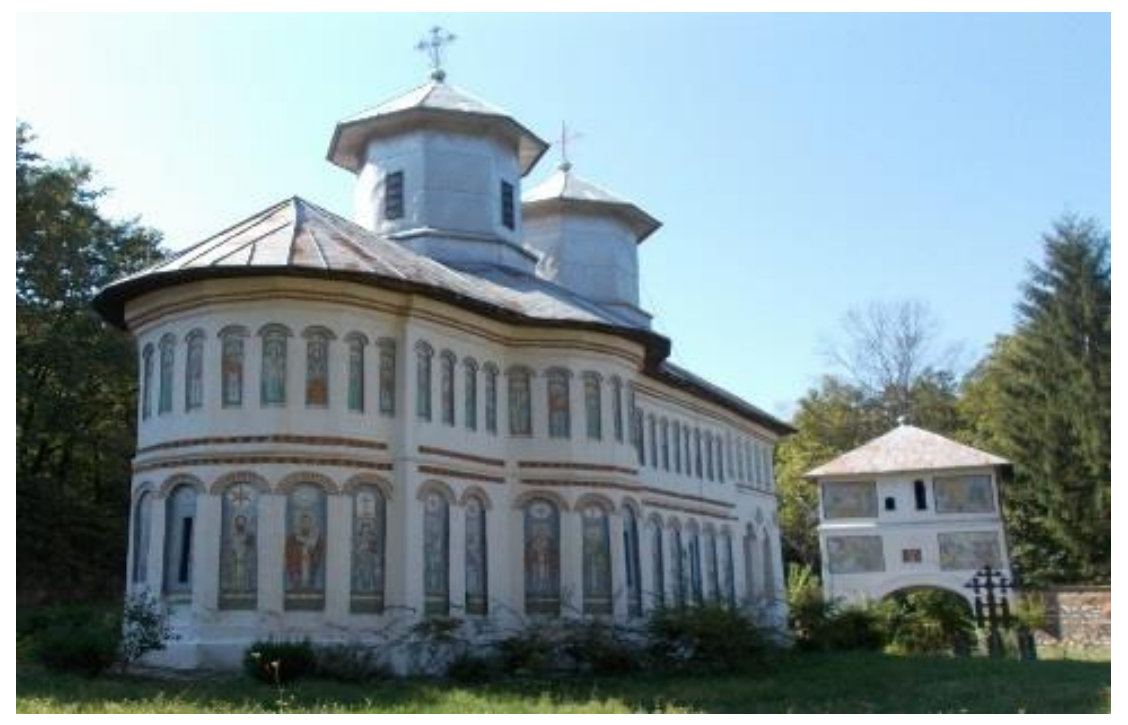

Fig. 2. The "Holy Apostles Peter and Paul" Church of the former Flămânda hermitage,

Valea Râului village, Galicea commune, Vâlcea county. View from the northeast.

(Photo: Bardan Petruța, 12. 09. 2020) 


\subsection{About church dating}

Regarding the dating of the place of worship, different opinions were issued: according to Victor Brătulescu, the former hermitage would have been built by Teodosie Rudeanu, in the first half of the 16th century (Brătulescu, 1934, p. 39); according to Nicolae Stoicescu, the church would have been built by the great logothetes Teodosie, at the end of the 16th century (Stoicescu, 1970, p. 306).

In two internal documents, from the second half of the 17th century, we find certain mentions about the acquisition of some estates, as well as about the moment of the construction of the former Flămânda hermitage. Thus, the document (hrisovul) of September 14,1651, records the fact that, during the reign of Mihnea II (1577-1583; 1585-1591), the great logothetes Teodosie obtained from Turcin's descendants, the "old man" of the owner from Pleșoi, the estates of Vlădeni and Slăvitești families (lorga, 1903, p. 680). In another document, dated September 15, 1654, it is specified that the old owners, ie the boyars Vlădeanu and Slăvitești, respectively "Tudor vel logofăt i Arsenie vel sărdari”, and they lost their estates, „in the year (leatul) of 7076 (1568-1569!)" (lorga, 1903, p. 680). During this time, one after the other Petru cel Tânăr (1559-1568) and Alexandru II Mircea (1568-1574; 1574-1577) ruled Wallachia (Rezachevici, 2001, p. 246, p. 255, p. 267), "being the boyars of Vlădeni, of Slăvitești, together with Turcin, fugitives for fear of Mihnea Vodă" (lorga, 1903, p. 680). At the same time, we find out that the fugitives returned to the country between 1594 and 1595 (lorga, 1903, p. 680).

Therefore, the place of worship was built by Teodosie Rudeanu, during the reign of Mihnea II, on the estates of Vlădeanu and Slăviteşti boyards: "they built up [...] a monastery called Flămânda [...], it happened that they built the wall on their piece of land (chingă de moșie)" (Iorga, 1903, p. 680).

Another document, dated June 15, 1659, reconfirms that the place where the hermitage was built was bought by Theodosius from Turcin's descendants, and an additional information we find out is that these descendants of Turcin's people were the Dăniceii (CDTTR, 2012, IX, p. 406, doc. 760). At the same time, the inscription on the tombstone of Stanca Rudeanu, dated May 28, 1584 (Bălan, 1994, p. 321, doc. 396), shows us that the works for the place of worship construction were already finished, when the Vlădeanu and Slăvitești returned from exile (lorga, 1903, p. 680).

\subsection{Regarding the votive painting in the narthex of the church and other data about the founders}

As it appears from the text of the inscription (Fig. 3), above the door at the entrance to the church "The Holy Apostles Peter and Paul", in the porch, the place of worship was repaired, in the nineteenth century, at the initiative of D. D Nichita, His Eminence Bishop of the Diocese of Argeș, and of the Commission of Historical Monuments, an important role being played by the parish priest N. Vasilescu Sachelar.

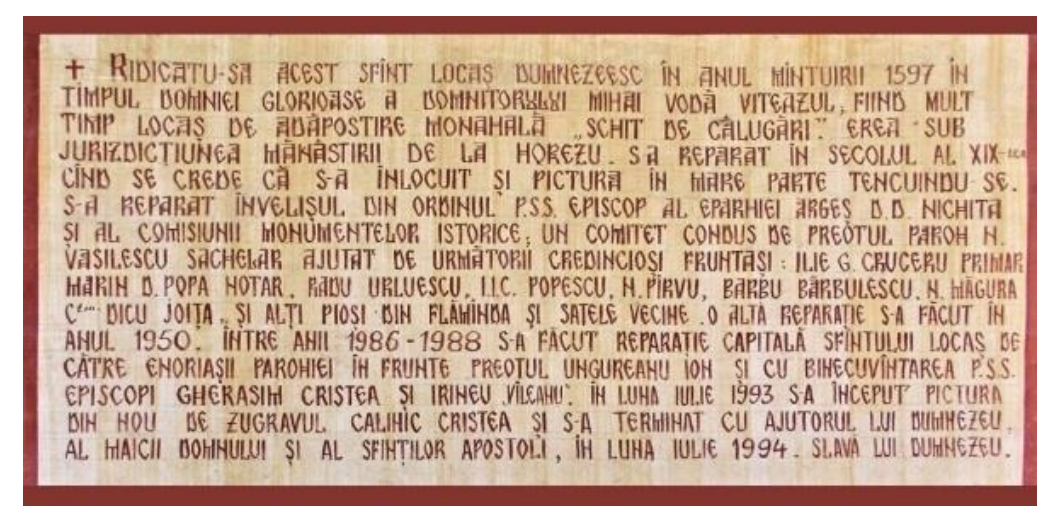

Fig. 3. The inscription of the "Holy Apostles Peter and Paul" church,

Galicea commune, Vâlcea County (Photo: Bardan Petruța, 12. 09. 2020)

During this period, the painting of the church was remade, this being subjected to another restoration effort, between July 1993 and July 1994, when the painting was remade again by the painter Calinic Cristea. Only on the basis of this information we do not know whether the initial painting of the founders' portraits or the inscription on them affected or to what extent this intervention affected them. What we know for sure is, in the Romanian Middle Ages, that when the votive paintings of the portraits of the founders of a place of worship were made, their high offices were not always correctly inscribed. A proof in this sense is the church 
from Ruda, also built by the Rudeanu family, where Tudor Rudeanu is wrongly mentioned as a dignitary who took care of the supply of the royal court with food such as bread, barley, oat (clucer), he was in fact dealing with the supply of the royal court with meat (sluger) (DIR, B, 1951, III, p. 611, doc. 545; DRH, B, 1969, XIII, p. 325 , doc. 198), in 1624, when the church was painted (Teodorescu, 1929, p. 173). Observing the texts of the inscriptions on the votive portraits of the founders of the church of the former Flămânda hermitage, we notice that "Stanca" and "Teodosie Rudeanu" are written in Romanian, as well as the high office held by Teodosie, in contrast to the Slavonic inscription on the votive painting of Tudor Rudeanu, from the church from Ruda. Here, Teodosie is incorrectly mentioned only as a subordinate of the great dignitary called "spătar", he actually having the title of the great dignitary under whose service he was (spătar), because he held the supreme command of the country`s army in the absence of the lord (vel spătar), between April 28 and September 24, 1584, in the time of Peter Cercel (Mioc et al, 1960, p. 571). Based on the above comparison, we could deduce that it intervened on the initial form of the text on the mural painting of the founders, renouncing the variant in the Slavonic language, specific to the Romanian Middle Ages, this being done in Romanian. In the future, it remains to be clarified, especially with the help of unique historical sources, how much was intervened regarding the painting of the portraits of the founders of the church from Flămânda, but also on the text of the initial mural painting.

The founders of the church are represented on the east wall of the narthex: Teodosie Rudeanu high official (vel spătar) (Mioc et al, 1960, p. 571; Stoicescu, 1971, p. 85), the son of the great logothetes Ivan from Ruda, and his first wife, Stanca. In the mural, Teodosie (Fig. 4), is represented still young, bearded, wearing a blue surplice (anteriu), over which there is another wider reddish coat. On the left side, next to him, appears theboyar's first wife, the young (jupânița) Stanca. She wears a white "hat" on her head and a yellow coat. The slightly oval head shows us two large eyes, a fine nose, a real beautiful little nobel woman (Fig. 5). As if her eyes, slightly sad, could tell, her unexpected end which was about to come in her thirtieth year of her life. The silhouette of the church is painted above the entrance to the nave (pronaos), being located between the two founders.

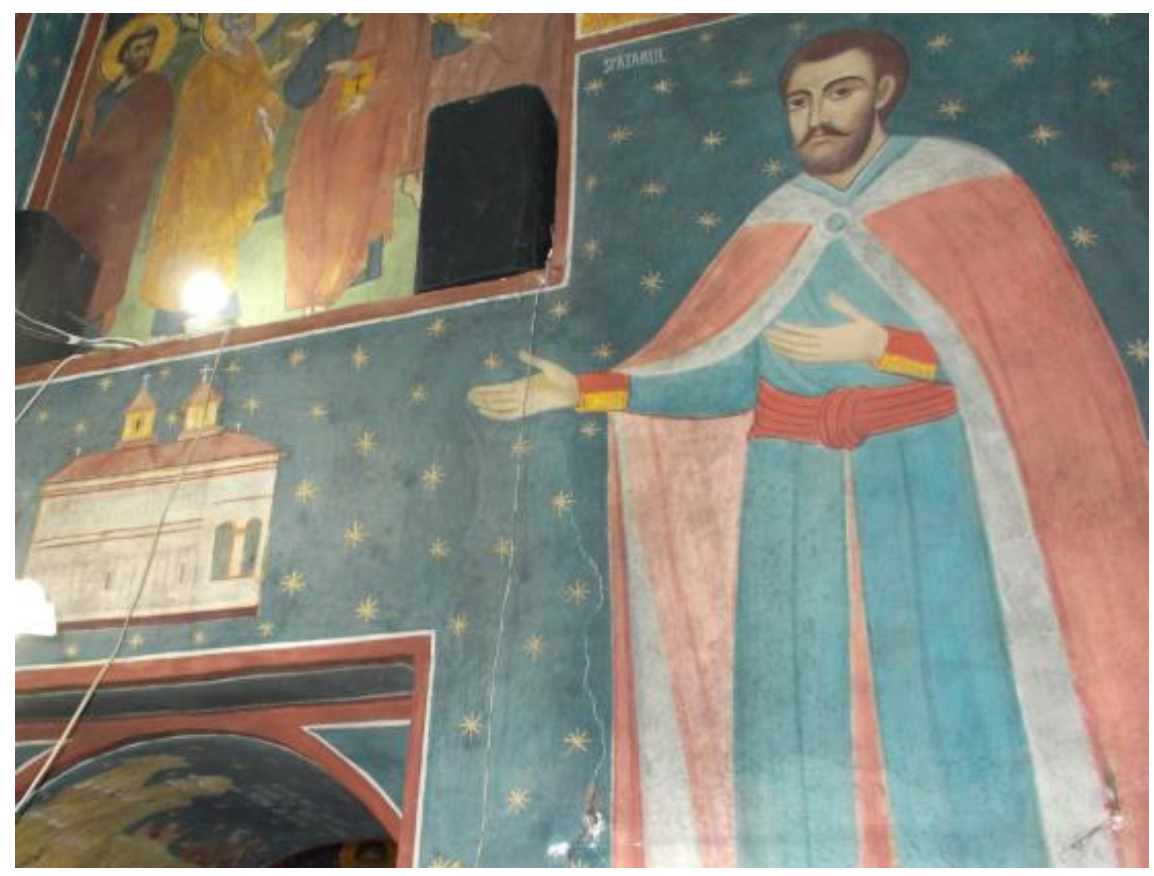

Fig. 4. Teodosie Rudeanu great high official (vel spătar), founder. His image illustrated on the eastern wall of the narthex of the church of the former Flâmanda hermitage, on the right, Galicea commune, Vâlcea county (Photo: Bardan Petruța, 12. 09. 2020) 


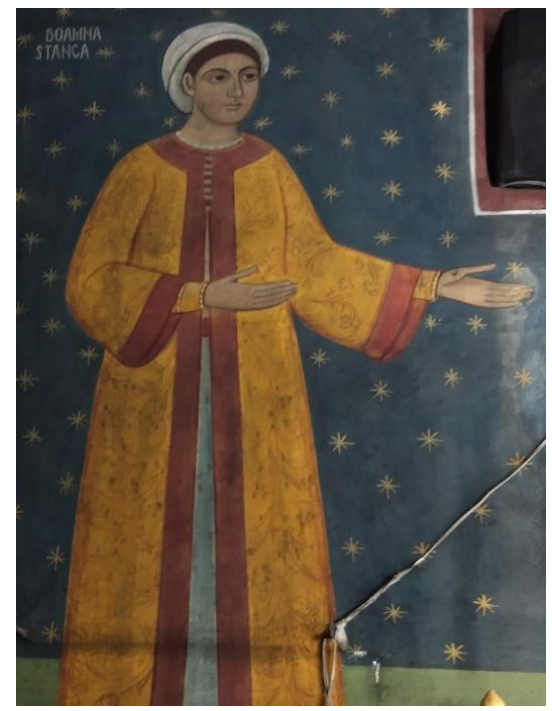

Fig. 5. Stanca, the boyar's first wife of Teodosie Rudeanu. Her image illustrated on the eastern wall of the narthex of the church of the former Flâmanda hermitage, on the left (Photo: Bardan Petruța, 12. 09. 2020)

In the narthex of the church can also be found two tombstones. On the left side of the room, under the tombstone, Stanca was buried, Teodosie Rudeanu's wife great official, on the day of the Ascension of the Lord, on 28 May 1584. Stanca, the daughter of Vlad ban from Cocorăști, died "in her youth at 24 years old" (Bălan, 1994, pp. 320-321, doc. 396). The inscription on the grave stone gives us some information about the character of Stanca, but also about the pain that caused her loss to the great high official: "and she was merciful" and "gentle at her house" (Bălan, 1994, pp. 320-321, doc. 396). On the right side of the narthex there is the grave stone of the great logothetes Teodosie Rudeanu.

The "Holy Apostles Peter and Paul" church, of the former Flâmanda place of worship, also has, on the right side of the narthex, another tombstone, where his founder, the master "Teodosie logofet, the virgin of the logothetes Ivan of Ruda", was buried (Bălan, 1994, p. 321, doc. 397). He was placed under the grave stone, on 28 May 1621, during the fourth reign of Radu Mihnea, lord of the Romanian Country (1620-1623), son of Mihnea II, on the same day of the Ascension of the Lord, but thirty-seven years after the death of his first wife: "they died in the days of Radul Voivode and Mihni Voivode, May 28 the year (văleat) 7129" (Bălan, 1994, p. 321, doc. 397).

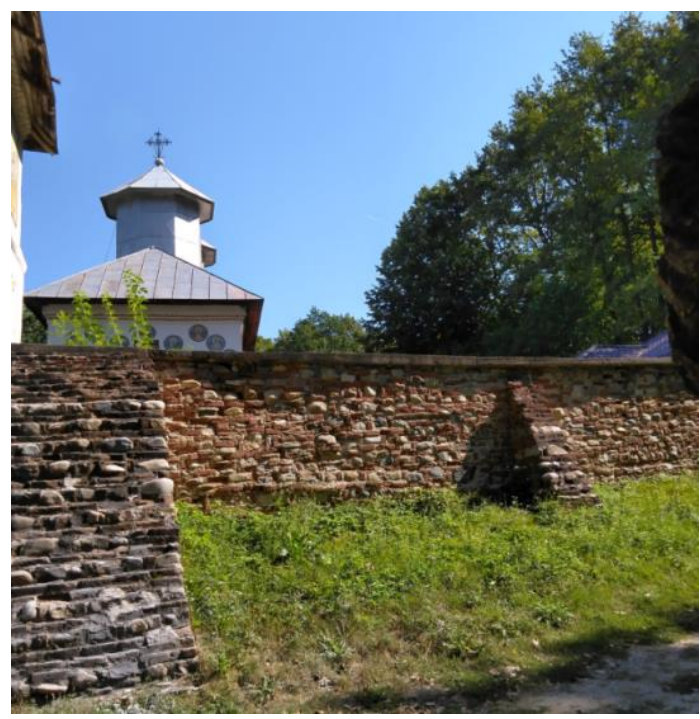

Fig. 6. The west side of the defensive wall surrounding the Church of the "Holy Apostles Peter and Paul" of the former Flâmanda place of worship (Photo: Bardan Petruța, 12. 09. 2020) 


\subsection{Some properties of the former Flâmanda place of worship}

The former Flămânda place of worship was mentioned, on 6 February 1620, in a strengthening book from the time of the reign of Gavril Movilă (1616; 1618-1620). The Voivode of the Monastery of Topolog, Arges County, "where the patron saint is the Holy Apostles Peter and Paul", the villages of Băiaşi, on Topolog, Arges County, and Turcenești, exempting them from the duty, "from the winery and all the fees, how many are over the year", ie namely from all the givings and services (DIR, 1951, III, pp. 475-476, doc. 432).

Later, on 25 May 1624, the Flâmanda place of worship appeared in another internal document issued during the reign of Alexander Coconul (1623-1627). By this reign act, the ruler of the establishment of the holy monastery called "de la Topolog", land at Gardești and Nănășeşti (DIR, 1954, IV, p. 411, doc. 425). Teodosie Rudeanu, together with his son Vlad the cup-bearer, had in their possession the lands (ocine) in Gardești, which were obtained by purchase (DIR, 1954, IV, p. 411, doc. 425).

A charter from Matei Basarab, dated 2 November 1635, records that, in the time of Radu Şerban (1601; 1602-1610; 1611), Vlad the logothetes of Ruda bought lands in Ninășeşti from Manea logothetes from Șirineasa. Vlad Rudeanu "dedicated" thisland to his "Monastery from Flămânda" (DRH, 1985, XXV, p. 157, doc. 152). However, the estate (moșia) in Ninășeşti briefly belonged to the Flâmanda place of worship, as Govora Monastery would also claim the land it had mastered in the past. Thus, following a judgment with Meletie, the abbot of Govora Monastery, Andrei Rudeanu the purveyor, son of Vlad Rudeanu logofat, lost this estate (DRH, 1985, XXV, p. 157, doc. 152).

\subsection{Fate of the place of worship in the time of the descendants of Teodosie}

The descendants of Teodosie Rudeanu would be judged, during the reign of Mihnea III th Radu (16581659), with the descendants of the Săviteşti and Vlădeni boyards for that "piece" (chingă) of the estate, on which Theodosie built the hermitage of Flămânda (CDȚR, 2012, IX, p. 406, doc. 760). The principle of the grandchildren of Teodosie Rudeanu was a great logothetes, respectively Vlad the cup-bearer, together with his brother, Radu postelnic, Preda cup-bearer, together with his brother, Tudosie, and Dumitrasco Murgescu postelnic, with the descendants of the Vlădeni and Slaviteşti, respectively Stepan Vlădeanu postelnic, Isac logothetes and his brother, Şerban postelnic, tried at the Monastery of Flâmanda, where "all of them gathered" (CDȚR, 2012, IX, p. 406, doc. 760). There was present the steward Nedeco the porter, as well as the grandchildren of the Danicei and other Rumans from Pleşoi and "from the land Gărdească and Gălicia, as they were bound by the border of the Pleşoi", but also elders, priests and people from the surrounding area. As a result of this judgment it was established that two lands, respectively Gărdească and Pleșoiască, together with the Rumans, should be given to the Vlădeanu and Slăvitești. The latter accepted that the "piece" of the estate, the Turcinească, should remain to the monastery, as the Rudeneanu had asked, and that they all should all be founders (CDȚR, 2012, IX, p. 406, doc. 760).

The monastic settlement of Flâmanda was under the iconography of the Rudeni boyars throughout the 17th century. A document from the reign of Constantin Brâncoveanu (1688-1714), dated 23 August 1699, records that, on this date, the hermitage was worshipped to the Diocese of the Râmnic by the descendants of Teodosie Rudeanu. Among the donor "founders" of this place of worship were: Hrizea and Apostolache, sons of Dumitrașco Rudeanu Lord steward clucer, Vlad and Socol, sons of Vlad Rudeanu cup-bearer, Constantin, son of Tudosie Rudeanu captain, Mihail, son of Radu Rudeanu postelnic, as well as the great logothetes Diicu Rudeanu (Iorga, 1903, p. 681). The document also stated that the Rudeanu donated this monastic settlement from Flămânda of Râmnic Diocese of their own free will: "all of us the founders, who are written above, of our own free will, unforced by anyone, have thought in our hearts for God and for the souls of our parents and ours, if we have given and worshiped the holy monastery of Flămândaby the Topolog river, ot sud Arges, where is the patron saint Saint Petru and Pavel, but all the villages and estates with the Rumans and the Gypsies, except the Rumans who are redeemed by the founders with deeds (zapise), and with all the income as it stands, to be all at the expense of the holy episcopacy, for we have worshipped her, of our good will" (Sfânta Episcopie a Eparhiei Râmnicului Noul Severin în trecut și acum, 1906, p. 380). From the deed we also learn that, when the place of worship was donated to the diocese, llarion was a bishop: "We write and confess by our deed so that it may be of great faith in the holy diocese of Râmnic, where it is the patron saint, the miracle maker Nicolae Miralichia, and in the hands of our honest priest Chir llarion, bishop of Râmnic, how to know when they were namely in the days of our Lord lo Constantin Basarab Voevod" (Sfânta Episcopie a Eparhiei Râmnicului Noul Severin în trecut și acum, 1906, p. 380).

However, these boyars, mentioned above, were not the only donors to the Diocese of Râmnicu. Thus, in Dyptychs No. 1, of Bishop Ștefan, page 5, other members of Rudeanu family are among the donors: "Stanca ot Albești, daughter of Radu logothetes ot Ruda", who offered all her part of the estate in Câmpul 
Râmnicului, "and the fourth part of the Rudeani estate", Dima Rudeanu, who gave a vineyard and an orchard, as well as other "boyars ot Ruda", who gave to the Râmnic diocese "a placein the water of Râmnicu" (Sfânta Episcopie a Eparhiei Râmnicului Noul Severin în trecut și acum, 1906, p. 246).

The deed of donation, of August 23, 1699, also specified that the hermitage from Fămânda would become the metoh of the Diocese of Râmnicu, the latter also having the "administration" of the villages, estates, Romanians and Gypsies that belonged to the former place of worship: "As such we gave our letter to the holy diocese so that the holy monastery of Flămândato be metohof the holy diocese, to protect all villages and estates and gypsies and Romanians the holy diocese" (Sfânta Episcopie a Eparhiei Râmnicului Noul Severin în trecut și acum, 1906, p. 380).

From a princely card sent to the Holy Episcopate of Râmnicul Noului Severin, on October 15, 1699, we find that Prince Constantin Brâncoveanu strengthened to Bishop lliarion the worship of the Flămânda monastery on the water of the Topologu, Arges County, dedicated to the Holy Apostles Peter and Paul. The voivode also strengthened the villages, the estates, the Romanians and the Gypsies, together with the incomes, to the holy Episcopate of Râmnicu (Bâzgan, 2009, p. 240, doc. 170).

\section{CONCLUSIONS}

The place of worship from Flămânda represented and still constitutes a remarkable architectural construction, worthy of the personality of its founder. Having a very important role in the history of Wallachia, Teodosie Rudeanu wanted to leave to posterity a testimony over the centuries of the prestige and rank he enjoyed in the time he lived. Being, at the same time, a cult boyar, Teodosie needed a space of spirituality and taste for beauty. The former Flămânda hermitage fulfilled both the religious function, serving as a place of prayer for the Rudeni boyars, and not only, but also the role of necropolis of the family.

The novelty of the research lies in the desire to contribute new information regarding the history of the former Flămânda hermitage, to bring to the public's attention this building, valuable from an architectural point of view, belonging to an emblematic character of the medieval history of Wallachia.

\section{REFERENCE LIST}

Bălan, C., (1994). Inscripţii medievale şi din Epoca Modernă a României. Județul istoric Argeș (sec. XIV1848). Bucharest: Romanian Academy Publishing House.

Bâzgan, M., (2004). Județele Țării Românești până la mijlocul secolului al XVIII-lea. Bucharest: University Book Publishing House.

Bâzgan, M., (2009). Condica Marii Logofeţii (1692-1714). Piteşti: Paralela 45 Publishing House.

Berechet, Ș., (1922). „Catagrafia episcopiei Argeșului în 1808”. In Biserica Ortodoxă Română XL, pp. 678686.

Brătulescu, V., (1934). „Biserici din Argeș și Vâlcea”. In Buletinul Comisiunii Monumentelor Istorice XXVII, pp. 39-47.

Bulat, T. G., (1922). „Inscripții din bisericile Olteniei”. In Arhivele Olteniei 1, pp. 244-252.

Ceaușescu, Anton, Mihaela-Marcela Pârvulescu and Emil Pârvulescu, (2021). Comuna Galicea-Vâlcea. Râmnicu Vâlcea: Bibliostar Publishing House.

Ghika-Budești, N., (1932). „Evoluția arhitecturii în Muntenia și în Oltenia”. In Buletinul Comisiunii Monumentelor Istorice XXV, pp. 58-64.

Fotino, D., (1859). Istoria Generală a Daciei, sau a Transilvaniei, Terei Muntenesci și a Moldovei. Bucharest: losef Romanov et Companie's National Printing House.

Ghenadie al Râmnicului. (1888-1889). „Introducere”. In Biserica Ortodoxă Română XII, 9, pp. 612-625.

Gheorghiu, T. O., (1985). Arhitectura medievală de apărare din România. Bucharest: Technical Publishing 
House.

Ionașcu, I., (1942). Catagrafia eparhiei Argeș la 1824. Bucharest: Church Book Printing House.

Ionescu, G., (1965). Istoria Arhitecturii în România. Bucharest: R. S. R. Academy Publishing House.

lorga, N., (1903). Studii și documente cu privire la istoria românilor. V. Bucharest: Publishing House of the Ministry of Instruction.

Mioc, D., C. Bălan, M. Bălan, N. Stoicescu, Şt. Ştefănescu. (1960). „Lista marilor dregători din Sfatul domnesc al Ţării Româneşti în secolele XV-XVII". In Studii şi Materiale de Istorie Medie IV, pp. 565583.

Mioc, Damaschin, (1969), Documenta Romaniae Historica, B. Țara Românească. XIII. Bucharest: Publishing House of the Academy of the Romanian Socialist Republic.

Mioc, Damaschin, Ștefan Ștefănescu, Marieta Adam, Constantin Bălan, Maria Bălan, Sașa Caracaș, Ruxandra Cămărășescu, Olimpia Diaconescu, Coralia Fotino. (1975). Documenta Romaniae Historica, B. Tara Românească. XI. Bucharest: Publishing House of the Academy of the Romanian Socialist Republic.

Mioc, Damaschin, Maria Bălan, Ruxandra Cămărășescu, and Coralia Fotino. (1985). Documenta Romaniae Historica, B. Tara Românească. XXV. Bucharest: Publishing House of the Academy of the Romanian Socialist Republic.

Monitorul Oficial al României, part I, no. 113 bis/15.02.2016.

Mușat Elena, Mirela Comănescu, Laura Niculescu, and Ileana Dincă. (2012). Catalogul documentelor Țării Românești din Arhivele Naționale. IX. Bucharest.

Rezachevici, C., (2001). Cronologia critică a domnilor din Tara Românească şi Moldova. Bucharest: Encyclopedic Publishing House.

Roller, Mihail, (1951). Documente privind istoria României, B. Tara Românească, veacul al XVII-lea. III. Bucharest: Publishing House of the Academy of the Romanian People's Republic.

Roller, Mihail, (1952). Documente privind istoria României, B. Țara Românească, veacul al XVI-lea. V. Bucharest: Publishing House of the Academy of the Romanian People's Republic.

Roller, Mihail, (1954). Documente privind istoria României, B. Țara Românească, veacul al XVII-lea. IV. Bucharest: Publishing House of the Academy of the Romanian People's Republic.

Sfânta Episcopie a Eparhiei Râmnicului Noul Severin în trecut și acum, (1906). București: Tipografia,,Gutenberg”, Joseph Göbl.

Simionescu, D., (1959). „Cronica lui Baltasar Walther despre Mihai Viteazul în raport cu cronicile interne contemporane". In Studii și Materiale de Istorie Medie. III, pp. 7-99.

Stoicescu, N., (1970). Bibliografia localităților și monumentelor feudale din Tara Romaneasca. Bucharest: Oltenia Metropolitan Publishing House.

Stoicescu, N., (1971). Dicționar al marilor dregători din Țara Românească și Moldova, sec. XIV-XVII. Bucharest: Encyclopedic Publishing House.

Teodorescu, G., (1929). „Biserica Ruda-Bârsești din comuna Bercioi-Argeș. Note asupra picturii. In Buletinul Comisunii Monumentelor Istorice XXII, pp. 173-177. 